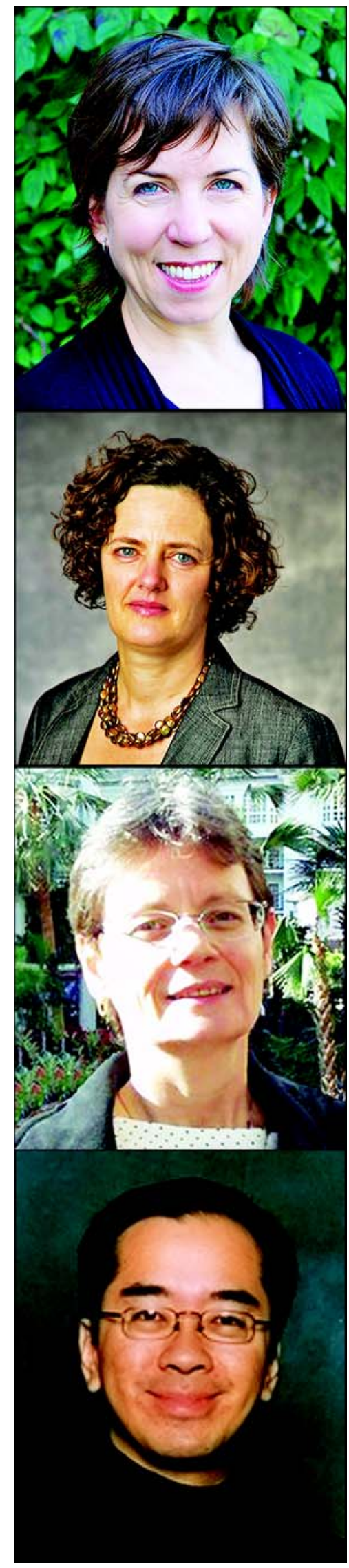

M. Kristi Henzel, MD, PhD; Kath M. Bogie, DPhil; Marylou Guihan, PhD; Chester H. Ho, MD

\section{Pressure ulcer management and research priorities for patients with spinal cord injury: Consensus opinion from SCI QUERI Expert Panel on Pressure Ulcer Research Implementation}

\section{OVERVIEW}

Pressure ulcers (PUs) are a serious and costly complication for many individuals with reduced mobility and sensation. Some populations, such as those with spinal cord injury and disease (SCI/D), remain at high risk throughout their lifetimes. Clinical observations and research have demonstrated staggering costs and human suf fering because of PUs, including profound negative effect on general physical health, social ization, financial status, body image, and level of independence and control [1-2]. The International Pressure Ulcer Prevalence Study from 2006 to 2009 demonstrated a change in PU prevalence in the U.S. healthcare facility population. Overall, PU prevalence was slightly lower in 2009 than in 2006, but prevalence of suspected deep-tissue injuries (DTIs) increased during the same period [3]. Further investigation into the cause of these changes is warranted. DTI diagnosis frequency may have been affected by the addition of suspected DTI to the revised National Pressure Ulcer Advisory Panel (NPUAP) staging definitions in 2007 and rule changes for Centers for Medicare and Medicaid reimbursement.

Consideration of current evidence-bas ed practice (EBP) is vitally important in the development and implemen tation of prevention, treatment, and rehabilitation strategies for PUs. A weal th of basic science is available, and early clinical trials are being carried out in the fiel $\mathrm{d}$ of PU research; many of these trials were presented at the inaugural International Evidence Based Practice in Wound Care conference in 2006. The focus of the 2nd International Conference on Evidence Based Practice in Wound Care: The Effective Implementation of Pressure Ulce r Clinical Practice Guid elines (held in 2009) was the apparent "disconnect" between these early-stage research efforts and their implementation as routine clinical practice, as documen ted in current clinical practice guidelines (CPGs).

EBP and expert opinion ar e frequently combined during the formulation of CPGs. The balance of expert opinion and EBP in a given CPG depends on the maturity and depth of the research base. Currently, there are multip le CPGs for ulcer prevention and treatment, including the Consortium for Spinal Cord Medicine Clinical Practice Guidelines on Pressure Ulcer Prevention and Treatment (SCICPG) [4]. The common goal of these CPGs is to reduce the incidence and prevalence of PUs. Un fortunately, Thomason et al. found that although SCI physicians and nurses generally agreed with the SCICPG recommendations as written, they did not believe that these recommendations w ere 
fully implemented in the ir respective clinical set tings. Furthermore, clini cal personnel identified lack of knowledge and or ganizational factors - such as communication difficulties across teams, shifts, and hospital departments - as th e biggest barriers to implementing CPGs [5]. The effective selection and implementation of evidence-based guidelines for PU are critically important to improving rehabilitative and lifetime outcomes for people at risk for PU develop ment. Education in the us e and implementation of CPGs is an ongoing need. Additionally, a critical need exists to ide ntify the remaining $r$ esearch gaps and pathways to ef fective implementation of research efforts in clinical practice.

An invited expert panel met in Cleveland, Ohio, on June 4, 2009, in conjun ction with the 2nd Inter national Conference on Evidence Based Practice in Wound Care, to develop a research agenda based on critical knowledge gaps regarding PUs in individuals with S CI and on i mplementation of adva nced clinical practice. We report a literature-based discussion of the consensus pa nel conclusions. The meeting was sponsored by the De partment of Veterans Affairs (VA) SCI Quality Enhancement Research Initiative (SCI QUERI).

The SCI QUERI works closely with the V A's SCI/D Strategic Health Group to identify the criti cal, time-sensitive issues important for $\mathrm{V}$ eterans Health Administration operations as part of the SCI QUERI mission: promotion of patient health, functioning, and quality of life through the implementation of evidence-based methods for enhancing patient self-management and disease $p$ revention in the context of multidisciplinary care. PUs are a significant clinical problem in the SCI population and are a primary area of research focus.

\section{PANEL FORMAT}

The multidisciplinary expert panel consisted of a balanced mix of clinicians and researchers, integrat ing physicians, nurses, engineers, and physical therapists with both health se rvices and rehabilitation researchers. VA research leaders attended, and the VA Rehabilitation and Res earch Service and the VA
Office of Nursing Service were also involved since a critical need re mains for preclinical and clinic al pilot-phase research in PU management (see Appendix for panel membership, available online only).

The panel's mission was to develop consensus on a focused research agenda to address the critical gaps extant in eviden ce-based knowledge of PU care and to facilitate large-scale implementation of advanced clinical practice.

Panel discussions were divided into three sessions: (1) primary prevention-reducing the incidence of PUs, identifying high-risk patients, and developing models of rehabilitation and education; (2) secondary prevention-performing early/routine assessments and reducing recurrence of PU; and (3) te rtiary prevention - treating and reducing disease-related complications [6]. Panel discus sions used the SCICPG as an underlying guide.

While panel discussions were segregated by pre vention level, several topics are clearly relevant to more than one aspect of PU prevention and/or man agement. For example, hete rotopic ossification (HO) is potentially important in both primary and secondary prevention. Therefore, our discussion in this ar ticle is organized by the overarching categories of risk factors (ranging from the cellular level to the patient and environment), clinical management (at the patient, clinical microsystem, and clinical macrosystem level), education (of patient, caregivers, clinicians, and administra tors), and environment of care (macrosystem).

The expert panel conducted a follow-up survey to prioritize the research gaps identified during panel discussions. Panel participants were asked to prioritize research topics, from the perspective of their indi vidual expertise, in the four domains discussed. Panelists ranked what they cons idered the most ur gent research areas using a mu ltiple selection format. Selections were limited to the top three research themes in the domains of risk factors and clinical management and the top two re search themes in the domains of education and environment of care. Validation measures were employed to ensure survey integrity. The survey was hosted on the online survey provider Question Pro (http://www.questionpro.com/). High-priority research top ics were designated based on percentage of panel responses. 


\section{PANEL FINDINGS}

\section{Risk Factors}

Reducing PU incidence and recurrence (primary and secondary prevention, respectively) depends on reliably identifying the risk factors that contribute to PU formation. It is well recognized that PU development involves multiple factors, and although many risk factor s have been identified, many key questions in PU development remain unanswered and are in need of further research. Clinically, it is not known why some individuals develop rec urrent PUs while others with similar predisposing risk factors remain PU free. This may be due to genetic predisposition, intrinsic infla mmatory states, baseline nutritional status, or ot her unknown reasons. For example, the duration of ap plied pressure is known to be important, but anecdotal information suggests that some people can sit for many hours a nd not exhibit tissue damage while others may exper ience skin breakdown if they do not rigorously adhere to a frequent pressure-relief regime. Clearly there is no "magic number" for a single universal "safe load ing" period or applied pr essure that will not cause tissue damage [7].

Risk factors are organized by the SCICPG into the following categories: demographics (e.g., patient age, time since injury, and education), physical/medical (e.g., level and completeness of injury, mobility, incontinence, and comorbidities), and psychosocial (e.g., psychiatric disorders, cognitive impairments, substance abuse, and co mpliance). The panel emphasized that, in add ition to the more easily quantifiable physical and biomechanical factors, it is important to review the psychosocial aspect s of PU risk status. As described in the CPG, psychosocial includes aspects of both patients' mental status (with specific emphasis on depression and anxiety) and psychosocial resources such as support networks and living situation.

\section{Population Risk Disparities}

Several disparities in PU risk based on popula tion warrant further research. While risk factors are widely agreed upon, the relative weight of these factors and their importance $\mathrm{w}$ ith respect to recurrence have not been established and probably vary across patient groups [8]. The panel considered that further research is needed to establish whether factors that predict $\mathrm{PU}$ recur rence in the SCI/D population are similar to those in other high-risk populat ions, such as the older population and individuals with multiple sclerosis. Even wit hin the SCI/D population there are differences between veterans and other SCI/D groups [9]. Much of the published research on risk factors for PUs focuse s on either nursi ng home residents or on the populati on with acute SCI/D; the degree to which these risk factors apply to other populations has not been established. VA hospitals have a high proportion of individuals with long-term, chronic SCI (time since injury approximately 20 years) [1011] who receive life-long care in both urban and rural areas, whereas M odel SCI Systems Centers focus primarily on acute traumatic SCI in the urban areas. PU risk factors may possibly differ between these populations. Recurrence rates are known to be significant, ranging from 31 to 79 percent [12-16]. Data exist on possible risk fa ctors for re current PUs; however, there is little information on characteristics of recurrence [17].

\section{Mechanical Risk}

The etiology and biomech anics of PU development remain topics for fu rther investigation. Clinically, it is known that tissue breakdown can originate both at the skin surface and in deep tissues [18-19]. Histological studies have shown that deep tissue often shows significa nt damage before any superficial damage is visible [20]. Recent preclinical studies indicate that deep-tissue loads, in par ticular internal strains, may be important factors [21-22]. Further preclinical studies are in progress to fully characterize these models. Research is also needed to establish the pa thway for translation and clinical practice implemen tation of biomechanical interventions to prevent skin breakdown.

\section{Cellular-Level Risk}

Biomolecular aspects of PU development are incompletely characterized and need further research. The effects of mechanical loading on cytokine release from the skin surface have been investigated in an in vitro model [23-24]. A pi lot study by Sari et al. 
evaluated creatine phosphoki nase levels in wound exudate as a potential indicator of DTI in an animal model [25]. In the field of diabetic ulcer management, nitric oxide levels in w ound fluid have recently been proposed as indicators of wound healing [26]. While using wound exudate as the source for biomarkers [27] could increase know ledge of the processes involved in tissue breakdow $\mathrm{n}$ and/or healing, implic itly this approach could not facilitate primary or secondary prevention. The pa nel considered that centralized banking of wound tissues could provide a resource to advance the basic research still required to understand the biochemical pr ecursors to PU devel opment. Several commercial tissue banks exist that can provide a variety of tissues. The National Disease Research Interchange (NDRI) is a not-for-profit corporation, supported by the National Institutes of Health, that provides huma $\mathrm{n}$ cells and tissues for research. Currently these tissue books tend to focus on specific disease etiologies, such as cancer, arthritis, and heart disease; however, NDRI could act as a bro ker to obtain wound tissues [28]. In addition, tissue from PU surgeries could be a valuable resource for tissue banking.

\section{Risk Assessment}

The panel recognized a continuing need for standardized assessment tools that would enable practitioners to identify PUs befo re tissue damage becomes clinically noticeable. Such tools are needed for all patient groups. The challenge of detecting early skin damage, i.e., stage I PUs, in individuals with darker skin is even greater than in the overall at-risk population. Advanced imaging techniques are being investigated that have the poten tial to improve primary prevention for these individuals [29-30]. Measure ment of subepidermal moisture has been reported as a potential technique for de tecting early PUs in ind ividuals with dark skin [31], thus improving care for this patient population. Multispectral imaging has been reported as a potenti al method for detecting erythema in individuals with dark skin pigment [32]. Initial e valuations have been performed of diagnostic ultrasound [33-36], three-dimensional elastography [37-38], and me thods to assess tissue viscoelasticity [39] for identifying and predicting progression of DTI to fulm inant PUs and assessing deep tissue strains in indi viduals with SCI. Further research is needed to establish reliability and ef ficacy in order to provide a sound basis for clinical imple mentation of interventions utilizing newer technolo gies for all individuals at risk for PU development.

\section{Physiological Risk}

The panel considered spec ific clinical facto rs within the SCI/D population that significantly affect PU risk status. For example, individuals with tetraplegia frequently have uncompensated hypotension combined with poor or absent venous return. These population-specific cardiovascular changes may be significant risk factors in PU development [40].

$\mathrm{HO}$ is also a well-know $\mathrm{n}$ complication of SCI and has been linked to PU incidence [41-43], but the mechanism driving unc ontrolled promotion of osteogenesis following SC I has not been investi gated. A recent study in pa tients with traumatic brain injury (TBI) indica ted that both osteoblast proliferation and differentiation are increased acutely following TBI [44]. Increa sed osteoblast activity is an indicator of $\mathrm{HO}$, suggesting that further research in the SCI population may be warranted. The pre cise relationship betwee $\mathrm{n} \mathrm{HO}$ and PU formation remains to be determined.

Although specific patie nt groups have been defined as being at high risk of PU development, the effect of comorbidities has not been investigated in the population with SCI. For example, chronic obstructive pulmonary disease (COPD) was found to be associated with PUs in an outpatient geriatric population [45]. This area of re search may benefit from preclinical modeling using the large databases available to VA researchers through the V A Information Resource Center [46] or the National Surgery Quality Improvement Program [47]. Additionally, the panel considered that clin ical studies are needed regarding the effect of factors such as diabetes and obesity on PU development and/or recurrence.

\section{Aging-Related Risk}

The risk of PU development and/or recurrence may also be af fected by comorbidities that develop over time. Extensive longitudinal cohort studies have 
shown that aging with an SCI accelerates degenera tive changes in health st atus [48-49]. Reports of the relationship between PU a nd time since injury are less consistent $[8,50-51]$. The panel co nsidered that research in the SCI vete ran population would be valuable in addressing these questions.

\section{Environmental Risk}

Knowledge of how extrin sic environmental fac tors contribute to forma tion and recurrence of PUs remains incomplete. Environmental risk factors include the local skin envi ronment (e.g., moisture level secondary to sweating and bowel or bladder incontinence), interface press ure and sh ear force between the skin and the support surface, friction [52], residential situation, and ps ychosocial support. These factors may interact with intrinsic physical/medical risk factors to increase PU risk. Certain environments are known to be associated with hi gher incidence of PUs, e.g., inte nsive care units (ICUs) and surgery. Recent VA quality improve ment data from $t$ he VA Nursing Outcome database * (second quarter of fiscal year 2008-final quarter of fiscal year 2010) indicate that the average rate of hospital-acquired ulcers is low $(2.2 \%)$ in VA SCI Centers. Further research into high-risk settings for PU development, especially for community-dwelling individuals with SCI/D, is warranted.

\section{Nutritional Risk}

The SCICPG suggest th at general nutritional status is important in PU development and healing. In addition, the NPUAP White Paper on the role of nutrition in preventing and treating PUs advises that early nutrition screeni ng provides a window for identification of PU risk. However, although the NPUAP provides guidelines for nutritional assess ment and management of individuals with preexisting PUs [53], there is little evidence supporting use of specific nutritiona 1 therapies for preventing and treating PU. Our panel deemed that further

\footnotetext{
*Internal communication: Office of quality and performance. VA Nursing Outcome database (V ANOD). Washington (DC): Department of Veterans Affairs; 2010.
}

research is needed into the ef fects of sp ecific dietary elements in individuals with $\mathrm{SCI} / \mathrm{D}$, e.g., the potential role of proinf lammatory diets in both acute and chronic SCI/D.

\section{Pressure Ulcer Risk Assessment}

As noted previously, it is well recognized that prevention of PUs involves many factors. The correction of all risk factors for an individual with SCI/D can be both overwhelming and imprac tical to implement in clinical practice. The relative importance of both independent and dependent risk factors for PU prevention has not been investigated. A pilot study to differentiate degrees of risk in criti cally ill people was reported over 15 years ago [54] but ha s not been further developed. The Salzberg risk assessment scale, developed for SCI, focused on 15 risk factors, including urinary incontinence, autonomic dysreflexia, card iac/pulmonary/renal/diabetic comorbidities, impaired cognitive function, cigarette smoking, residence in a nursing home or hospital, hypoalbuminemia, and anemia [55-56] but has not been further evaluated for validity and reliability [3]. The panel suggested that research is needed to develop weighted models of risk factors to enable ef ficient direction of clinical resources for effective primary PU pr evention in the population with SCI/D.

The panel concluded that standardized and com prehensive documentation of PU risk factors and treatments could potentially help reduce both PU development and recurrence rates. Clinical and health services research is needed to develop and implement appropriate and effective documentation.

\section{Education}

Education and awareness are critically important to prevent PUs. Educational programs may be directed to healthcare prof essionals, i.e., physicians, nurses, and nursing assistants, as well as to individu als with SCI, their fa milies, and caregivers. The SCICPG recommend providing these individuals with information on ef fective strategies to prevent and treat PUs [4]. The panel discussed the continuing need for research regarding the most ef fective ways to educate all groups involved in PU prevention. 
Knowledge of how best to educate patients and providers is necessary for the development of comprehensive and effective tools tailored to the individual's learning style. T o be effective, education must motivate the at-risk individual and his/her provider to both learn and act on the information.

Effective primary prevention requires accurately identifying at-risk individuals, implementing appropriate preventative measures, and identifying early-stage tissue damage. Continuing education and collabora tion is required to mainta in the knowledge needed to perform these tasks. In the acute setting, education of clinical staff is important to improve PU awareness and to promote primary prev ention strategies. Studies have shown that there is wide variation in nursing knowledge and implementati on of PU preventive measures [57]. A significa nt drop in PU knowledge retained by critical-care a nd medical-surgical nurses was found 3 months after part icipation in a tar geted learning activity [58]. Quar terly continuing education on PU prevention for all clin ical staff involved with care of persons with SCI ma y be beneficial. Further research is needed to el ucidate best practice for con tinuing education regarding primary prevention of PUs in the acute period post-SCI.

Nosocomial development of primary and recurrent PUs also varies in dif ferent healthcare settings and/or populations. In part icular, serious illness requiring ICU admission and prolonged sur gical procedures will both affect overall risk status. However, the primary risk fact ors involved will vary by patient and by setting. The panel considered that specific guidelines are needed for healthcare professionals working in thes e settings. Research is needed both to develop appropriate guidelines and to increase awareness amongst acute-care providers who traditionally may not regard PU prevention in populations with $\mathrm{SCI} / \mathrm{D}$ as a priority.

Many clinical programs have recognized the need for early and comprehensive patient education during SCI rehabilitation. Sheppard et al. found that patients who had developed skin breakdown had poor knowledge about skin care [59]. This suggests that reinforcement of $\mathrm{p}$ atient education at every practical opportunity woul d be highly beneficial. The panel considered that it was also important for nonprofessional caregivers, such as family mem bers, to be included in the educational process.

The SCICPG suggest th at appropriate educa tional programs, which empower patients to take responsibility for skin care, are valuable for decreasing recurrence. However, research is needed to determine which approaches work best for different populations of individuals with SCI. Some research suggests that incentives can improve patient and provider participation in skin protective behaviors [60-61]. Determ ining of which incen tives are ef fective, sustainable, and reproducible remains an area for future research.

Tertiary prevention of PUs is focused on mini mizing the incidence of further related complications. The VA "Hub-and-Spoke" sy stem was desi gned to ensure that all veterans with SCI have access to rele vant clinical expertise. Within the veterans healthcare system, the SCI Ce nter is the hub, with some less specialized PU care provid ed at the spoke facilities within the hub's associated SCI ser vice areas. The educational goals for clinical teams at $\mathrm{V}$ A spoke facilities include knowledge of PU risk factors and potential complications. The pa nel considered that further research is needed to evaluate how to ef fectively disseminate information on best practices to spoke site community providers.

\section{Clinical Management}

Clinical management of PU prevention and treatment is complex because of the many risk factors and environmental contributions to their formation. The SCICPG includes 32 separa te recommendations. It would be very challenging and unrea listic to expect all recommendations be implemented concurrently. Providers and patients may feel overwhelmed by the numerous instructions for managing PUs. Moreover, few of these recommendations are evidence-based.

The clinical decisionmaking process is further complicated by the fact that the SCICPG weight all recommendations equally, which does not aid clini cians during a clinical decisionmaking process that is characterized by multiple competing priorities. The panel recommended further evaluation of the ef fect of adhering to all CPG-recommended behaviors. The effect can be studied from several angles, including 
clinical outcomes such as decreased incidence and reduced recurrence rates.

\section{Planning for Prevention}

The SCICPG support tailo ring PU prevention programs to specific patient populations. Key differences exist between the popul ation of persons with $\mathrm{SCI} / \mathrm{D}$ and other at-risk groups (such as elderly nursing home residents) in mu scle remodeling and atro phy [62-64]. For example, the primary diagnosis of $\mathrm{SCI} / \mathrm{D}$ is a much more st able condition than the degenerative aging process, and loss of appetite is more frequent in the olde $r$ population than in the $\mathrm{SCI} / \mathrm{D}$ population. Thus, patient-specific risk factors and overall treatment needs are different.

The panel determined that additional research is needed in clinical care planning for PU prevention. The majority of at-risk patients, particularly indi viduals with $\mathrm{SCI} / \mathrm{D}$, can ne ver be considered riskfree, although the absolute level of risk for an individual may vary over time. Furthermore, the predominant risk factors in the acute-care setting are different from those in community-dwelling population or long-term-c are settings. The panel considered that research is needed to determine the need for different clinical care planning to address the different effects of episodically varying risk factors such as infection and chronic risk factors such as muscle atrophy.

The panel discussed clin ical-care planning for continuous PU prevention and unanimously agreed that all PUs may not be preventable. A 1-day consensus panel on this issue wa s hosted by the NPUAP in February 2010 [65]. Given that the strongest predic tor of PU development is having had a previous ulcer, anyone with a previ ous PU has to be consid ered at high risk for recurrence [66]. At present, the long-term follow-up of i ndividuals whose PUs are healed varies. No evidence is available to guide clinical practice on what types of follow-up interventions these high-risk individuals should receive once their ulcer is healed. In many case $\mathrm{s}$, clinical staff is s o busy treating PUs that pr evention may not receive attention or resources adequate to address the magnitude of the problem. It may be more effective to manage individuals with SCI/D and a history of PUs as if they have a chron ic systemic disease, similar to diabetes or COPD. For example, to optimize skin health, continuing risk-factor management and patient/caregiver awareness training should be provided to reduce both recurrence and further complic ations. The panel discussed whether a patient-centered or wound-centered approach wo uld be more ef fective for long-term prevention. Pa tient-centered treatment models are relatively novel in PU management, and the panel considered that clinical research studies are needed prior to implementation.

\section{Acute Care and Bed Rest}

The SCICPG recommen d universal precautions for PU prevention, including turning every 2 hours while in bed for at-risk i ndividuals. While this is a standard practice in the Un ited States, the clinical practice in Europe (guided by the European Pressure Ulcer Advisory Panel guidelines) recommends individualized repositioning frequency based on patient factors and support surface [67]. The research basis for the 2-hour recommendati on is inadequate [68]. Moreover, a recent meta-analysis by Krapfl and Gray found limited evidence that 4-hourly turning, when combined with an appropriate pressure redistribution surface, is equally ef fective as a 2-hourly turning regime [69]. The panel agreed with the SCICPG authors in recommending that further research is needed to determine optimal turning intervals.

The SCICPG recommend implementing PU pre vention strategies during acute SCI to avoid prolonged immobilization. Unfortunately, implementation can be difficult during the acute postinjury period in the presence of bulky but medically necessary devices such as ventilators and external fixation devices. Optimally identifying at-risk individuals and early tissue damage and implementing preventive measures require an interdisciplinary team that brings together many dif ferent clinical skills. The implementation of interdisciplinary wound teams and specialized "turn teams" has been correlated with reduce $\mathrm{d}$ incidence of PUs at a 11 levels of patient care [70-73]. However, these teams were frequently implemented at the same time as other interventions. Therefore, the specific ef fect of the wound teams is dif ficult to ascertain without fur ther research. 
Determination of best practices for team com position and interaction is likely to be critically important [74]. It is rec ognized that not all disci plines will have the sa me professional education background or educational approach to PU management. It is not clear what knowledge the team leader should have, what discip lines ought to be repre sented on the team, or wh at frequency of rounding is needed for optimal management of PUs. In addi tion to tea $\mathrm{m}$ structure, it is nece ssary to es tablish guidelines for team inte ractions and communica tions, such as using di gital images to monitor wound healing and implem enting wound-care templates in the electronic medical records. Research is needed to determine the most effective techniques to promote interdisciplinary knowledge sharing and long-term implementation into routine practice.

\section{Skin Assessment}

Best practices for conducting skin inspections and wound-care rounds in hospitals have not been established. Likewise, the frequency and techniques for skin inspection in either the home or long-termcare setting are ill-defi ned. Despite the SCICPG recommendation for daily vi sual and tactile skin inspections, the expert panel agreed that visual skin assessment (VSA) remains an inadequate method for accurate prediction of PU development. There is evidence that VSA is difficult to carry out routinely for patients and provide rs. Although several risk assessment tools are currently in use, most of these tools demonstrate inappropriate sensitivity and specificity when applied to individuals with SCI/D. In addition, there appears to be some disagreement on the clinical ef fect of implementing routine risk assessment [75-77]. The expert panel considered that further research on how to provide timely and accurate feedback about risk factors to individuals with SCI/D and their caregivers is sorely needed.

\section{Tissue Health Assessment}

Although the assessment of PU risk is the goal of the SCICPG, several known risk factors cur rently cannot be assessed practically. For example, both normal and shear for ces are known to be sig nificant risk factors. Clin ical pilot studies have shown a strong associati on with duration of load ing, particularly acutely following traumatic SCI [78-80]. Assessing shear di rectly would aid risk assessment. While theoretical models of the ef fect of shear stresses have been developed [81-83], appropriate sensors are at an early stage of development for clinical use [84]. The panel considered that research is needed to validate mathematical models incorporating the ef fects of shear stresses and to develop shear measurement devices. This preclinical research is needed prior to implementation as a component of clinical management.

\section{Support Surface Technology}

Although the SCICPG r ecommends many sup port surface and positioning methods for preventing and treating PUs, no uniform method or schedule for conducting a seating/support surface evaluation is available. Variability in data collection, interpretation, and use of quantitative measures is a barrier to the development of eviden ce-based guidelines for seating prescriptions [85-86]. For example, the best way to use the informati on obtained through inter face pressure mapping is unknown [87]. The panel considered that further research is needed on support surface technologies and their implementation.

The standard of care for PU healing remains pro longed bed rest. In individua ls with $\mathrm{SCI} / \mathrm{D}$, this is associated with other comorbidities, loss of function, and social isolation. Although prone carts are routinely used in the rehabilitation ho spital setting, they remain impractical for use in most community settings. Cur rent research into altern ating-pressure support-surface technologies may redirect the PU prevention and treatment approach to pressure relief [88]. Ultimately, however, despite all improvements in support surface technology a universal optimal therapy is unlikely . Research-based principles that would allow individu alized treatments based on each person's array of risk factors and environment have yet to be developed.

\section{Pressure Ulcer Treatments}

PU management can be classified broadly as either conservative or surgical. Conservative management can include both systemic (e.g., nutritional) and topical interventions (e.g., dressing change). 
Treatments for PUs vary wi dely based on the stage and characteristics of the wound, e.g., amount of drainage, bacterial load, and presence of slough or eschar. The multiplicity of factors makes determin ing the standard treatment protocol for PUs difficult. Good data on which patients would benefit from conservative as opposed to surgical treatment are lacking. It may be beneficial to develop an algorithm or decision tree for PU treatment. Further research is needed to determine which treatments best promote complete healing under wh at circumstances. Ulti mately, the development of evidence-based g uidelines for the personalization of PU care would be beneficial.

Even when certain PU principles are commonly accepted, further research is required to determine best practices. For exampl e, provision of a moist healing environment is known to promote ulcer healing [89-91], but optimal conservative methods for controlling moisture in the wound require fur ther research. Controlled cl inical studies of topical agents in PU manageme nt, a commonly accepted practice, have tended to use pre-post test study designs, focusing on interventions involving a sin gle product [92-93]. A comp arative effectiveness trial would be lar ge and likely to become rapidly obsolete since new agents and dressings are continuously being released. A st andardized assessment methodology based on quantita tive benchmarks for wound healing would facilit ate direct comparison of different types of intervention.

Another commonly accepted principle for wound healing is debridement. De bridement is a technique employed to remove necrotic materials from the PU and to promote healing. It can be divided into three major categories: enzymatic, mechanical, an $d$ sharp debridement. There are currently n o standardized guidelines for best clinical practices in debridement to facilitate PU healing. The panel considered that clinical research is needed to determine both selection of technique and timing of debridement.

The surgical management of PUs remains con troversial because of the high rate of recurrence after flap closure [16,94-96]. Further research is needed to clarify the role for sur gery in PU treatment, because many questions remain. For example, it is unknown whether surgical intervention decreases recurrence of PUs compared with more conservative treatments or whether it may increase in cidence of PUs in other locations during the recovery process. There are other important postoperative practices for individuals with $\mathrm{SCI} / \mathrm{D}$ for which there is little evidence to guide care, such as length of bed rest and progression of seating trials, which remain largely based on clinician prac tice and preference rather than empirical evidence. Collaboration between sur geons and re habilitation teams in postoperative care may improve outcomes [97]. Further research is needed to determine the best clinical pathways for surgical management of PUs. Topics of interest include management of the preand postoperative risk fact ors, identification of the patient and provider factors that are most predictive of surgical success, determination of the intr aoperative precautions that should be taken to prevent additional skin breakdown, and establishment of the best practices for closu re surgeries to improve success rates and decreased recurrence. Additionally , the panel is still concerned regarding how to sustain adequate surgical support to perform these challenging surgeries in the future.

\section{Home Management}

PU prevention and treatment for the person with $\mathrm{SCI} / \mathrm{D}$ living at home vary widely depending on a number of factors, includi ng the individual's level of injury and functional abil ity; availability of sup port services such as home nursing and health aides; and caregiver availability, clinical skills, and physical abilities. Demands on patients and caregivers dealing with a PU at hom e can be overwhelming, especially when external resources are limited. The panel recommended further research on best prac tices for helping caregivers manage at home.

The panel discussed the role that communica tions or distance technology could play in improving patient home care by co ntinuing patient education and interactions with clin icians. Patient-specific information on PU risk factors could be made available to individuals, either on demand or regularly. In turn, the individual with SCI/D could have improved remote access to relevant information and expert clinical advice. The enhancement of patient/clinician 
interactions, with person alized near-real-time feedback, could facilitate secondary prevention of PUs. Research is needed to evaluate whether technologies such as home telehealth, social messaging platforms, text messages, or "blogs" would promote adoption of protective behaviors and/ or early notification of tissue damage, i.e., stage I PUs [98-99] when potentially, clinicians have an opportunity to make a difference in the course of the ulcer.

\section{Recurrent Pressure Ulcers}

The NPUAP staging model states that once a PU develops, it is always de scribed as at the maximum stage [100]. For example, if an individual has a grade IV right ischial PU during acute rehabilita tion, any further right ischial breakdown should always be classified as grade IV. The current NPUAP terminology implies that this grading system should be applied even if the second event is 20 years later and only involves superficial breakdown. However, the panel deemed that the lack of a reliable and valid classification system for staging recurrent PUs is problematic. Should a wound returning a month later in a person with a healed PU be considered new or old? If a wound develops elsewhere but tunnels to a previous PU site, is this classified as the same ulcer? These issues should be systematically addressed to determine the true prevalence and incidence of recurrent PUs.

\section{Characterization of Wound Healing and Chronic Wounds}

The current staging model also lacks clarification of the various physiological phases of wound heal ing. It is important to clea rly develop a standardized definition of healing and a reliable way to determine if a wound is fully healed. The relationships between the clinical appearance of a healing wound, the physiological properties of the wound, and clinical outcomes are not well understood. Current definitions of wound healing include epith elialization or covering over of the wound ar ea and require a temporal com ponent to be clinically re levant. It would be benefi cial to determine whether biomechanical information, similar to studies of tensile skin strength following surgical incisions, may be applied to healing $\mathrm{u}$ lcers to help quantificatify $h$ ealing. This would $r$ equire development of both a precis e clinical definition of wound closure, e.g., wound epithelialization, and a physiological definition based on the tensile strength of wound tissue and collagen organization. At this time, we lack cost-ef fective and noninvasive tech niques that can be applied clinically to determine whether a wound is fully he aled. Research in these areas would help determ ine which tr eatments promote complete healing.

Complicating the staging of PUs in individuals with SCI/D are those patie nts who develop chronic nonhealing ulcers. Further study is needed to determine at what point a woun $\mathrm{d}$ should be categorized as nonhealing. It is unclear whether patients can live safely with prolonged op en wounds because of a lack of longitudinal studie s of nonhealing PUs. We need a more rigorous clinical definition of recur rence in nonhealing wounds. Clinical approaches to managing patients with chronically nonhealing wounds remain ill-defined and should be further investigated.

\section{Tertiary Prevention of Complications}

Conventionally, long-term bed rest has been an important component of conservative management for PU healing. In individuals with SCI/D, bed rest is associated with loss of function and other comorbidities such as deconditioni ng, respiratory compromise, and social isolation [101]. Deconditioning, in turn, increases the ris $\mathrm{k}$ of furt her complications such as pneumonia, with a highly deleterious effect on patient recovery. It may therefore be beneficial to allow patients to mobilize before a PU is fully healed. Questions remain regarding the appropriate therapy regi men to prevent complicati ons of immobility. For example, should bedside ca rdiovascular exercise be used routinely to prevent deconditioning? If so, how should it be implemented su ch that worsening of the pressure ulceration is prevented? There is no evidence to guide clinical practice in determining activity lev els to protect respiratory and functional health during conservative PU management. The panel considered that clinical s tudies are needed to evaluate wheth er PUs can heal ef fectively without complete bed rest. As a corollary to this approach, development of evidence-based activity crite ria would be inv aluable 
for safely increasing sitting time and patient discharge to the community prior to healing.

Comprehensive assessment of the patient is important, as emphasized in the SCICPG , because PU development is considered a serious complication of $\mathrm{SCI} / \mathrm{D}$, which is associ ated with additional lifethreatening complications. The most frequent cause of death among veterans with SCI/D was sepsis associated with genitourinar y and PU sequelae [102]. However, the current mortality rate for PU-related complications in the population with SCI/D is not well characterized.

Multiple morbidities are associated with presence of PUs, such as osteomyelitis, bacteremia, and sepsis [103-104]. PU surgeries have been associated with wound dehiscence, postoperative hematoma/seroma, necrotizing fasciitis [105], and development of new intraoperative PUs. The incidence and prevalence of these complications are va riably defined. The best means for tertiary prevention of such complications also remain unclear. Once complications develop, treatments remain largely provider-dependent rather than being primarily evidence-based. Additional research is recommended in these areas.

As previously stated, i ndividuals with SCI/D are always at some level of risk for developing PU and subsequent infection. There is particular concern for patients with chronic nonhealing wounds, who typi cally have polymicrobial wound colonization associ ated with slowing of the wound healing process [106]. Colonization may eventually lead to local osteomyelitis or systemic infections. Though not the current practice, long-term prophylactic antibiotics have been used in the prevention of urinary tract infections and other complications of SCI/D [107]. Some clinicians believe these antibiotics may be useful for treating chronic osteomyelitis. However, it is unclear whether longterm prophylactic antibiotics ar e beneficial in tertiary prevention of morbidity and mortality due to SCI/Drelated wound infection. Unfo rtunately, this strategy may also lead to the evolu tion of antibiotic-resistant bacteria and cause dif ficulty in identifying ef fective therapy [108-109]. The panel considered that addi tional research is needed to evaluate the relative benefits of long-term antibiotic $\mathrm{s}$ with res pect to tertiary prevention of PU complications in SCI.

\section{Environment of Care}

The provision of care for preventing and treating $\mathrm{PU}$ in persons with SCI/D occurs in a variety of settings, from the acute to chronic, from inpatient to the community. Patient needs and the reso urces available for care vary based on level of injury and socioeconomic factors: level of education, insurance availability, and family support structure, to name a few. Consequently, there are significant challenges to care planning in this population, such as how to optimize provider team awareness, personnel/care giver planning and stability, and administrative support of care systems in the population with SCI/D.

The SCICPG support tailoring PU prevention programs to specific patient populations. Facilities need to determine the best way to implement and maintain the SCICPG. However, all recommendations are given equal weight of importance, which is impractical for clinical implementation and may impair the capability of healthcare systems to prioritiz e how limited resources are allocated. As mentioned, the ef fect of adhering to CPG-recomme nded behaviors can be studied from several perspectives, which may include outcomes such as cost-benefit analysis, quality improvement, risk management, and patient satisfac tion. Research is needed to develop appropriate and weighted guidelines that would optimize allocation of resources for all levels of prevention.

It is believed that curr ent distribution of health care resources focuses more on treatment of PUs and their morbidities than on primary prevention. Unfortunately, the complete true costs of PU prevention and care - ranging from direct clinical expenses such as treatments and dur able medical equipment to indirect costs such as loss of income, mobility , and independence - remain unknown. From the system standpoint, desire for lower costs and decreased liability may drive calls for the derivation of evi dence-based-care algorithms from weighted CPGs, e.g., implementation of multidisciplinary wound teams in the acute and long -term acute care facility. It is important, therefore, to determine the cos teffectiveness of specific treatments and prevention activities [110-111]. Further research is needed in this area. 
The exact circumstances under which veterans with SCI/D continue to receive care for skin breakdown at VA spoke sites vers us being transferred to the hub site for PU care are not well understood. If PU care was more formally comanaged between the hub and spokes, real-time information on the num ber of stage II or grea ter ulcers and available resources to manage them could be shared. There would be better information about the magnitude of the problem within the system of care and there could be more centralized discussion about how best to deploy resources under this scenario. Technology, including video conf erencing or other tele health applications, may facilitate such clinical collaboration on care for patients at remote sites.

Recent External Peer Review Program data suggest that in the population of veterans with SCI/ $\mathrm{D}$, the majority of P Us are acquired at home. Most prevention strategies address the role tha $t$ institutions play in prevention. However, very few lar ge scale studies address how best to help communitydwelling persons with SCI prevent skin breakdown. Further implementation research is $\mathrm{n}$ eeded in this area. For example, studies focused on the dischar ge planning interface between hospital care and home care would be beneficial. Research is needed on best practices for providing cont inuity of home care to meet the PU prevention and treatment needs of patients with SCI.

\section{RESEARCH PRIORITIZATION SURVEY RESULTS}

Panel participation in the survey was 81.8 per cent. In the area of risk factor research ( Figure 1), the panel's highest-priority research topics are advanced imaging for early PU detection (18.5\%), biomarkers for PU development (18.5\%), deep tissue load and internal-tissue strains $(11.1 \%)$, nutritional status and management ( $11.1 \%)$, and weighted risk

\footnotetext{
*Internal communication: Performance measurement reports. Washington (DC): Veterans Health Administration Office of Quality and Performance; 2010.
}

factor models (11.1\%). For education (Figure 2), the panel's highest-priority research topics are the development of ef ficacious learning tools for patients (33.3\%), development of ef ficacious learning tools for caregivers $(22.2 \%)$, and promotion of interdisci plinary team knowledge (22.2\%). In clinical management (Figure 3), the highest-priority research topic is the pathway for conservati ve and sur gical management $(18.5 \%)$, followed by the effect of interdisciplinary wound teams $\left(\begin{array}{ll}1 & 1.1 \%\end{array}\right)$, standardization of seating/support surface evaluation (11.1\%), and telehealth assessment (11.1\%). Highest-priority research topics in environment of care ( Figure 4) include the systematic implementation of standardized PU ca re programs (38.9\%), methods for effective transition of PU care from the inpatient to home settings (22.2\%), and best practices for the management of patients with SCI and PU who reside far from an SCI Center $(16.7 \%)$. The panel hopes that the coordinated development of this prioritized re search agenda will spur future PU research and in crease funding sources to finance such endeavors.

\section{CONCLUSIONS/RECOMMENDATIONS}

The consensus of the pane 1 is that several critical knowledge gaps exist in the PU research base. One of the largest issues is our current inability to predict when an individual with SCI/D is developing an occult PU. Resear ch on biomarkers of PU formation and healing and advanced imaging tech niques for early PU detection are very high-priority items. Better understanding of nutritional risk fac tors and therapies, as well as enhanced insight into the relationship between in ternal tissue forces and PU formation, will also aid us in the principal goal of primary prevention.

The panel also opined that we are falling short in our efforts to educate patients, families, and caregivers about optimal PU prev ention and care in com munity settings. Developing effective learning tools for patient, family, and caregiver education on both prevention and treatment of PUs is a high priority . There also remains room to improve our utilization 


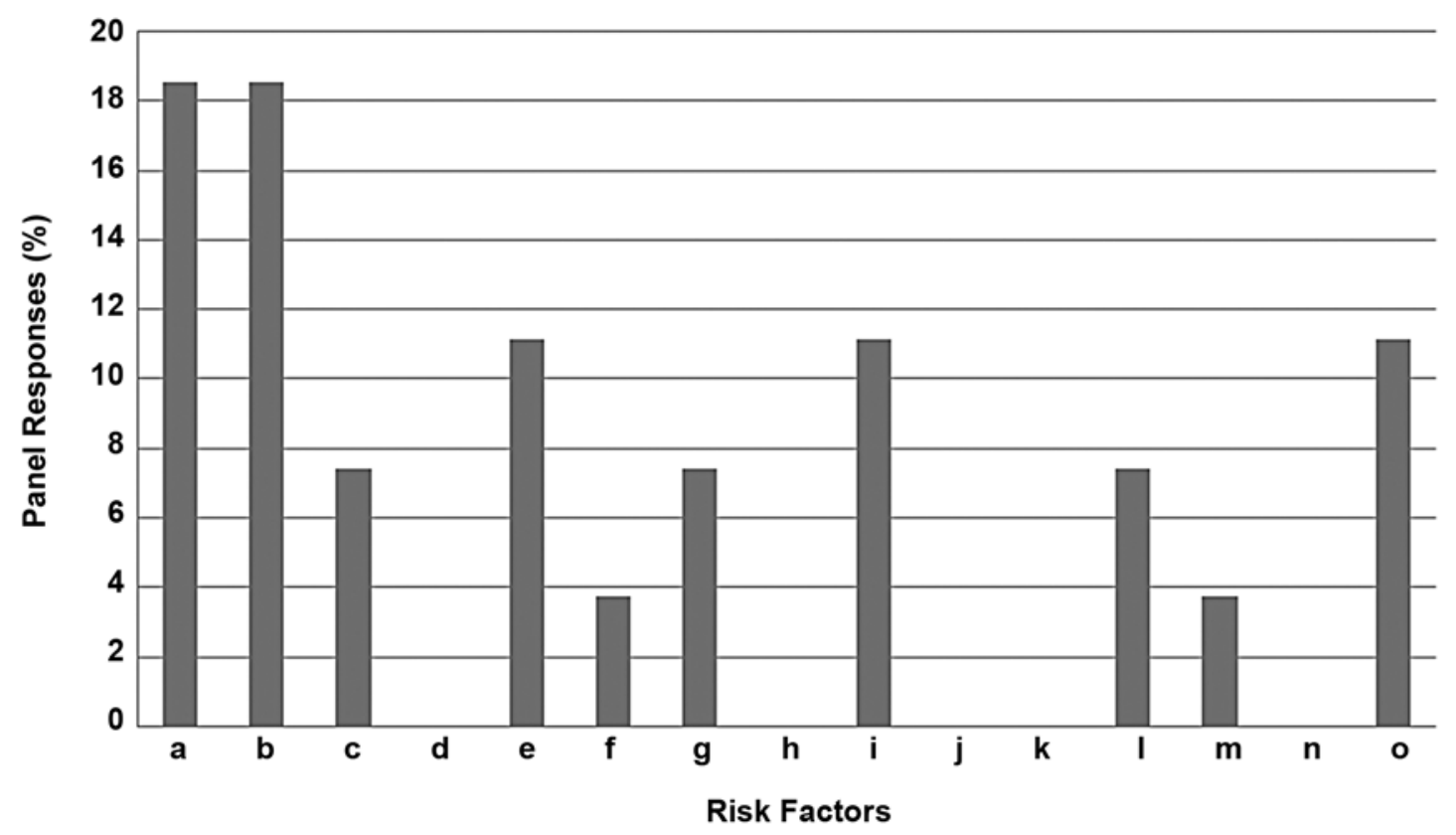

Figure 1.

Highest priority risk factor research. (a) Advanced imaging for early pressure ulcer (PU) detection, (b) biomarkers for PU development, (c) biomarkers for PU healing, (d) chronic systemic inflammatory states, (e) deep-tissue load/internal tissue strains, (f) genetic predisposition, (g) effect of comorbidities on PU risk in spinal cord injury (SCI), (h) microenvironment, (i) nutritional status and management, (j) physiology of PU, (k) psychosocial risk factors, (l) risk assessment tools for SCI, (m) risk factors for recurrent PU, (n) factors associated with agi ng with SCI, and (o) weighted risk factor models. Research topics $\mathbf{d}, \mathbf{h}, \mathbf{j}, \mathbf{k}$, and $\mathbf{n}$ had $0 \%$ response rate.

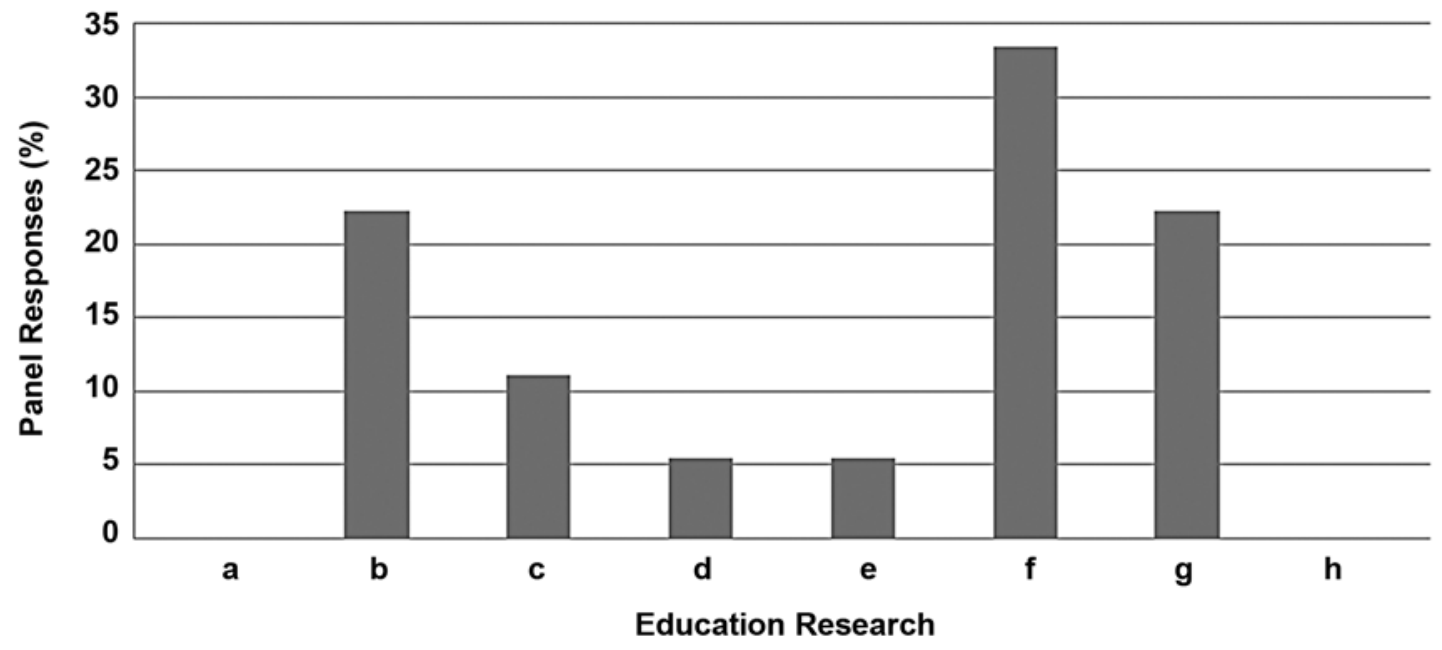

Figure 2.

Highest priority education research. (a) Continuing clinical education content/frequency, (b) development of efficacious learning tools for caregivers, (c) development of efficacious learning tools for families, (d) development of efficacious learning tools for inpatient clinical staff, (e) development of efficacious learning tools for outpatient clinical staff, (f) development of ef ficacious learning tools for patients, (g) promotion of interdisciplinary team knowledge, and (i) telehealth education. Research topics $\mathbf{a}$ and $\mathbf{h}$ had $0 \%$ response rate.

of interdisciplinary teams for preventing and treat ing PUs in the inpatient setting.

From the clinical manage ment perspective, the panel considered that rese arch to more rigorously define pathways for both conserva tive and sur gical management of PUs is most important, together with the need to stan dardize of evaluation methods for seating and support-surface interfaces. The effect of 


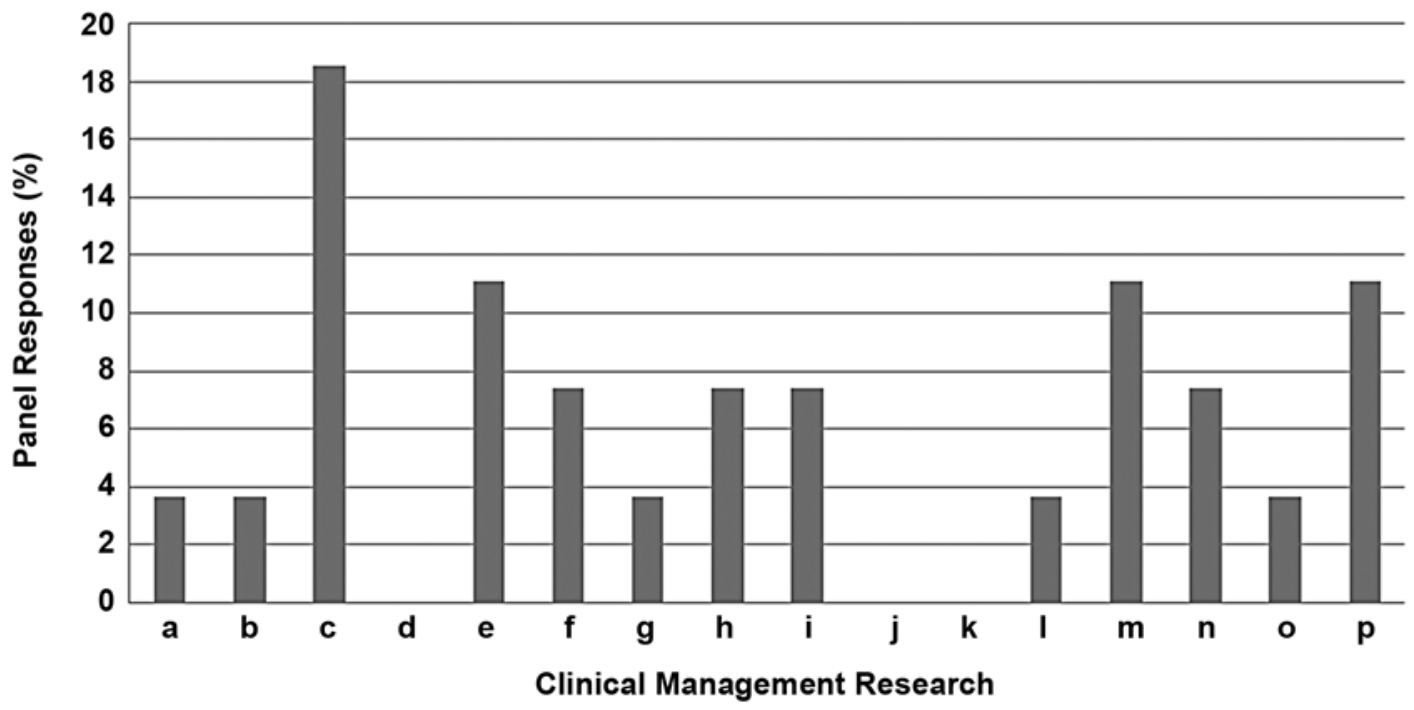

Figure 3.

Highest-priority clinical management research. (a) Avoidance of deconditioning during bed rest, (b) best practices for home care management, (c) clinical pathway for conservative and surgical management, (d) effect of "Turn Teams"/turn frequency, (e) effect of interdisciplinary wound teams, (f) long-term surgical outcomes, (g) monitoring frequency of turning, (h) patient-centered treatment models, (i) personalized treatment planning, (j) selection of conservative pressure ulcer interventions, (k) staging of recurrent PU, (l) standardization of clinical documentation, (m) standardization of seati ng/support surface evaluation, (n) support surface technologies, (o) surgical techniques for PU tre atment, and (p) telehealth assessment. Research topics $\mathbf{d}$, $\mathbf{j}$, and $\mathbf{k}$ had $0 \%$ response rate.

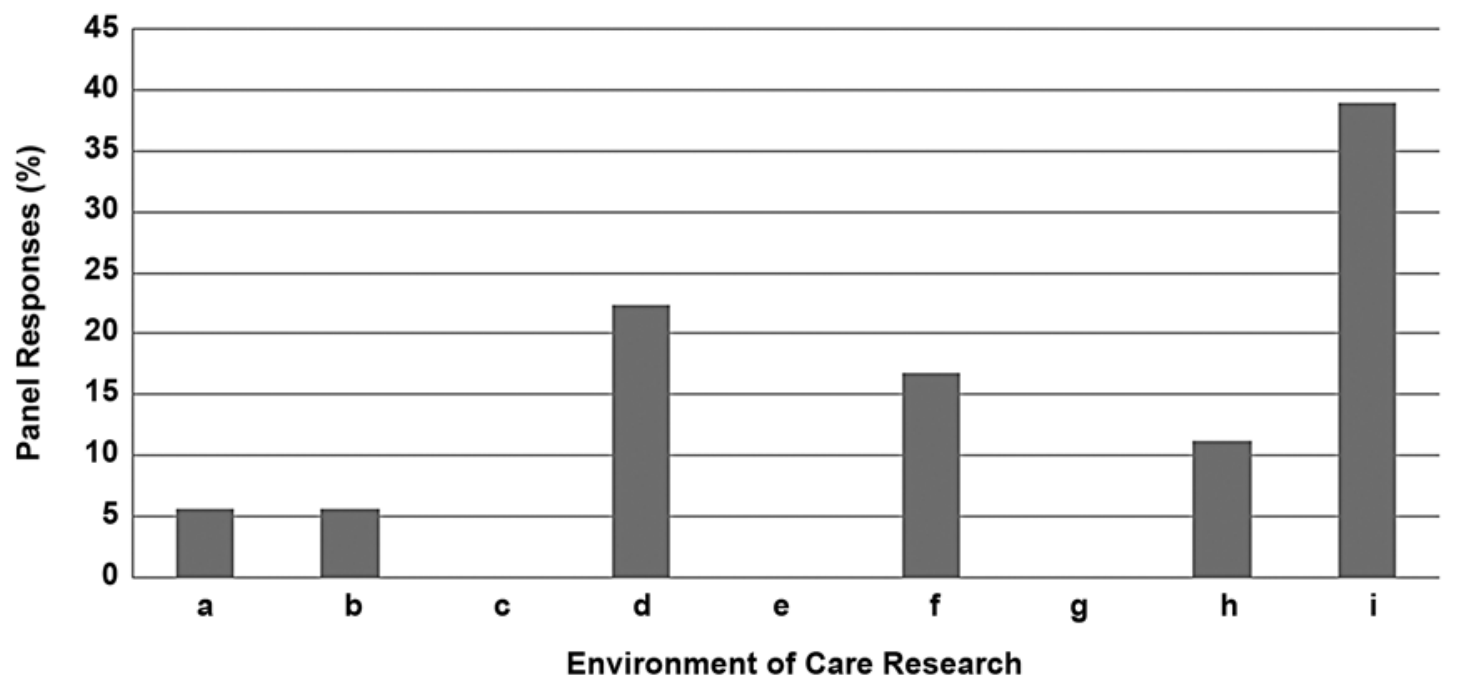

Figure 4.

Highest-priority environment of care research. (a) Allocation of resources for pressure ulcer prevention, (b) cost-effectiveness of PU prevention, (c) cost-effectiveness of PU care and treatment, (d) effective transition of PU care from inpatient to home settings, (e) high-risk settings for PU development, (f) management of geographically distant persons with SCI and PU, (g) optimizing inpatient care, (h) optimizing outpatient care, and (i) systematic implementation of standardized PU care programs. Research topics $\mathbf{c}, \mathbf{e}$, and $\mathbf{g}$ had $0 \%$ response rate.

interdisciplinary wound teams is also of high interest because they are believed to improve both prevention and healing of PUs in hosp ital settings. Furthermore, improved understanding of the appropriate implementation of telehealth evaluation methods may help pre - vent and treat PUs in individuals with $\mathrm{SCI}$ and $\mathrm{PU}(\mathrm{s})$ in the community setting.

Research on the environment of care ranging from inpatient to community settings remains underdevel oped. The panel deemed systematic implementation of 
standardized PU prevention and care programs the highest priority.

Clearly, many critical multidisciplinary targets remain for PU res earch, ranging from primary to ter tiary prevention, from cellular mechanisms of healing to treatment methodologies. Extensive research is needed in the basic sciences and clinical applications, as well as on the lar ge scale implementation of evi dence-based clinical practice. The panel identified several important areas of research within the CPGs. The panel also concluded th at certain evidence-based research on SCICPG topics, such as tissue-imaging technology, is nearing read iness for implementation trials.

It is a lso important that research addresses path ways to change in the healthcare system to effectively put new findings into ope ration. Effective change requires a culture of $\mathrm{c}$ ontinuous educations and improvement, complimented by a willingness to change when new evidence becomes available. It may be beneficial to model our efforts on VA National Systems Redesign techniques [1 12$]$ to expe dite timely adoption of EBP for preventing and treating PUs. Successful advancement of PU prevention across the $\mathrm{V}$ A system will decrease treatment costs and improve quality of life for our veterans with SCI/D. It may also serve as a model for care system changes for indi viduals with SCI/D ac ross the country and throughout the world.

\section{ACKNOWLEDGMENTS}

We would like to thank the panel members who com pleted the prioritization survey following the meeting.

This material was supported in part by Health Services Research and Development Se rvice, Quality Enhancement Research Initiative (grant RPP 09-118).

\section{Kristi Henzel, MD, PhD; ${ }^{1}$ Kath M. Bogie, DPhil; ${ }^{2-3^{*}}$ Marylou Guihan, PhD $;^{4-5}$ Chester $H$. Ho, $M D^{1,6}$ \\ ${ }^{1}$ Spinal Cord Injury Service and ${ }^{2}$ Cleveland Advanced Platform Technology Center and Func- tional Electrical Stimulation Center, Louis Stokes Cleveland VA Medical Center, Cleveland, $\mathrm{OH}$; ${ }^{3}$ Department of Orthopaedics, Case Western Reserve}

University, Cleveland, OH; ${ }^{4}$ SCI QUERI and Center for Management of Complex Chronic Care, Edward Hines Jr. VA Hospital, Hines, IL; ${ }^{5}$ Institute for Healthcare Studies, Feinberg School of Medicine, Northwestern University, Chicago, IL; ${ }^{6}$ Department of Physical Medicine and Rehabilitation, Case Western Reserve University, Cleveland, $\mathrm{OH}$

\section{*Email: kmb3@case.edu}

DOI:10.1682/JRRD.2011.01.0011

\section{REFERENCES}

1. Langemo DK, M elland H, Hanson D, Olson B, Hunter S. The lived experience of having a pressure ulcer: A qualitative analysis. Adv Skin W ound Care. 2000;13(5):225-35. [PMID: 11075022]

2. Clark FA, Jackson JM, Scott MD, Carlson ME, Atkins MS, Uhles-Tanaka D, Rub ayi S. Data-based models of how pressure ulcers deve lop in daily-living contexts of adults with spinal cord injury. Arch Phys Med Rehabil. 2006;87(11):1516-25. [PMID: 17084129] DOI:10.1016/j.apmr.2006.08.329

3. VanGilder C, MacFarlane GD, Harrison P, Lachenbruch $\mathrm{C}$, Meyer S. The demographics of suspected deep tissue injury in the United States: An analysis of The International Pressure Ulcer Prevalence Survey, 2006-2009. Adv Skin Wound Care. 2010: 23(6):254-61. [PMID: 20489387] DOI:10.1097/01.ASW.0000363550.82058.7f

4. Consortium for Spinal Cord Medicine Clinical Practice Guidelines. Pressure ulcer prevention and treatment following spinal cord injury: A clinical practice guideline for health-care professionals. J Spinal Cord Med. 2001;24(Suppl 1):S40-101. [PMID: 11958176]

5. Thomason SS, Evitt CP, Harrow JJ, Love L, Moore DH, Mullins MA, Powell-Cope G, Nelson AL. Providers' perceptions of spinal cord injury press ure ulcer guidelines. J Spinal Cord Med. 2007;30(2): 117-26. [PMID: 17591223]

6. Health promotion glossary [Internet]. Geneva (Switzerland): World Health Organization; 1998 (cited 2011 Jan 5). Available from:

http://www.who.int/hpr/NPH/docs/ hp_glossary en.pdf

7. Oomens CW, Loerakker S, Bader DL. The importance of internal strain a s opposed to interface pressure in the prevention of pr essure related deep tissue 
injury. J Tissue Viability. 2010;19(2):35-42. [PMID: 20005716] DOI:10.1016/j.jtv.2009.11.002

8. Chen Y, Devivo MJ, Jackson AB. Pressure ulcer prevalence in people with spinal cord injury: Ageperiod-duration effects. Arch Phys Med Rehabil. 2005;86(6):1208-13. [PMID: 15954061] DOI:10.1016/j.apmr.2004.12.023

9. Hedrick B, Pape TL, Heinemann A W, Ruddell JL, Reis J. Employment issues and assistive technology use for persons with spinal cord injury. J Rehabil Res Dev. 2006;43(2):185-98. [PMID: 16847785] DOI:10.1682/JRRD.2005.03.0062

10. Favazza T, Midha M, Ma rtin J, Grob BM. Factors influencing bladder stone formation in patients with spinal cord injury. J Spinal Cord Med. 2004;27(3): 252-54. [PMID: 15478528]

11. Smith BM, Evans CT, Kurichi JE, W eaver FM, Patel N, Burns SP. Acute respiratory tract infection visits of veterans with spinal cord injuries and disorders: Rates, trends, and risk factors. J Spinal Cord Med. 2007;30(4):355-61. [PMID: 17853657]

12. Krause JS, Broderick L. Patterns of recu rrent pressure ulcers after spinal cord injury: Identification of risk and protective facto rs 5 or more years after onset. Arch Phys Med Rehabil. 2004;85(8):1257-64. [PMID: 15295750]

DOI:10.1016/j.apmr.2003.08.108

13. Schryvers OI, Stranc MF, Nance PW . Surgical treatment of pressure ulcers: A 20-year experience. Arch Phys Med Rehabil. 2000;81(12):1556-62. [PMID: 11128889] DOI:10.1053/apmr.2000.17828

14. Niazi ZB, Salzberg CA, Byrne DW, Viehbeck M. Recurrence of initial pressure ulcer in persons with spinal cord injuries. Adv Wound Care. 1997;10(3): 38-42. [PMID: 9306777]

15. Holmes SA, Rintala D, Garber SL, Friedman JD. Prevention of recurrent pressure ulcers after myocutaneous flap. J Spinal Cord Med. 2002;25(Suppl 1):S23.

16. Goodman CM, Coh en V, Armenta A, Th ornby J, Netscher DT. Evaluation of results and treatment variables for pres sure ulcers in 48 vetera $n$ spinal cord-injured patients. Ann Plast Surg. 1999;42(6): 665-72. [PMID: 10382806] DOI:10.1097/00000637-199906000-00015

17. Bates-Jensen BM, Guihan M, Garber SL, Chin AS, Burns SP. Characteristics of recurrent pres sure ulcers in veterans with spinal cord injury. J Spinal Cord Med. 2009;32(1):34-42. [PMID: 19264047]
18. Bouten CV, Oomens CW, Baaijens FP, Bader DL. The etiology of pres sure ulcers: Skin deep or muscle bound? Arch Phys Med Rehabil. 2003;84(4): 616-19. [PMID: 12690603] DOI:10.1053/apmr.2003.50038

19. Berlowitz DR, Brienza DM. Are all pres sure ulcers the result of deep tissue injury? A review of the literature. Ostomy Wound Manage. 2007;53(10):34-38. [PMID: 17978413]

20. Edsberg LE. Pressure ulcer tissue histology: An appraisal of current knowledge. Ostomy Wound Manage. 2007;53(10):40-49. [PMID: 17978414]

21. Gefen A, Van Nierop B, Bader DL, Oomens CW . Strain-time cell-death threshold for skeletal muscle in a tissue-engineered model system for deep tissue injury. J Biomech. 2008;41(9):2003-12.

[PMID: 18501912]

DOI:10.1016/j.jbiomech.2008.03.039

22. Ceelen KK, Stekelenburg A, Loerakker S, Strijkers GJ, Bader DL, Nicolay K, Baaijens FP, Oomens $\mathrm{CW}$. Compression-induced damage and internal tissue strains are related. J B iomech. 2008;41(16): 3399-3404. [PMID: 19010470] DOI:10.1016/j.jbiomech.2008.09.016

23. Cornelissen LH, Bronneberg D, Bader DL, Baaijens FP, Oomens CW. The transport profile of cytokines in epidermal equi valents subjected to mechanical loading. Ann Biomed Eng. 2009;37(5): 1007-18. [PMID: 19234790]

DOI:10.1007/s10439-009-9652-y

24. Cornelissen LH, Bronneberg D, Gibbs S, Bouten CV, Oomens CW. Cytokine rele ase in tiss ue-engineered epidermal equivalents after prolonged mechanical loading. Methods Mol Biol. 2010;585:335-44. [PMID: 19908014] DOI:10.1007/978-1-60761-380-0 23

25. Sari Y, Nakagami G, Kinoshita A, Huang L, Ueda K, Iizaka S, Sanada H, Sugama J. Changes in serum and exudate creatine phosphokinase concentrations as an indicator of deep tissue injury: A pilot study. Int Wound J. 2008;5(5):674-80. [PMID: 19134069] DOI:10.1111/j.1742-481X.2008.00543.X

26. Boykin JV Jr. Wound nitric oxide bioactivity: A promising diagnostic indicator for diabetic foot ulcer management. J Wound Ostomy Continence Nurs. 2010;37(1):25-34. [PMID: 20075688]

27. Wyffels JT, Fries KM, Randall JS, Ha DS, Lodwig CA, Brogan MS, Shero M, Edsberg LE. Analysis of pressure ulcer wo und fluid using two-dimensional electrophoresis. Int Wound J. 2010;7(4):236-48. 
[PMID: 20492013]

DOI:10.1111/j.1742-481X.2010.00672.x

28. Intergumentary system [Internet]. Philadelphia (PA): National Disease Research Interchange; 2007 (cited 2011 Jan 5). Available from:

http://www.ndriresource.org/Donor Programs/

Tissue Banks/Integumentary System/119/.

29. Rajendran PJ, Leachtenauer J, Kell S, Turner B, Newcomer C, Lyder C, Alwan M. Impro ving the detection of stage I pressu re ulcers by enhancing digital color images. Conf Proc IEEE Eng Med Biol Soc. 2006;1:5206-9. [PMID: 17946685]

DOI:10.1109/IEMBS.2006.259514

30. Sprigle S, Linden M, Riordan B. An alysis of localized erythema using clinical indicators and spectroscopy. Ostomy Wound Manage. 2003;49(3):42-52. [PMID: 12732750]

31. Bates-Jensen BM, McCreath HE, Pongquan V. Subepidermal moisture is associated with e arly pressure ulcer damage in nursing home residents with dark skin tones: Pilot findings. J W ound Ostomy Continence Nurs. 2009;36(3):277-84. [PMID: 19448508]

32. Sprigle S, Zhang L, Duckworth M. Detection of skin erythema in darkly pigmented skin using multispectral images. Adv Skin Wound Care. 20 09; 22(4):172-79. [PMID: 19325277] DOI:10.1097/01.ASW.0000305465.17553.1c

33. Aoi N, Yoshimura K, K adono T, Nakagami G, Iizuka S, Higashino T, Araki J, Koshima I, Sanada H. Ultrasound a ssessment of deep tissue injury in pressure ulcers: Possible prediction of pressure ulcer progression. Plast Reco nstr Surg. 2009; 124(2):540-50. [PMID: 19644272]

DOI:10.1097/PRS.0b013e3181 addb33

34. Andersen ES, Karlsmark T. Evaluation of four noninvasive methods for examination and characterization of pres sure ulcers. Skin Res Technol. 2008; 14(3):270-76. [PMID: 19159371] DOI:10.1111/j.1600-0846.2008.00290.x

35. Makhsous M, Venkatasubramanian G, Chawla A, Pathak Y, Priebe M, Rymer WZ, Lin F. Investigation of soft-tissue stiffness alteration in denervated human tissue using an ultrasound indentation system. J Spinal Cord Med. 2008;31(1):88-96.

[PMID: 18533418]

36. Quintavalle PR, Lyder CH, Mertz PJ, Phillips-Jones $\mathrm{C}$, Dyson M. Use of high-resolution, high-frequency diagnostic ultrasound to investigate the pathogenesis of pressure ulcer de velopment. Adv Skin Wound
Care. 2006;19(9):498-505. [PMID: 17132955]

DOI:10.1097/00129334-200611000-00010

37. Deprez JF, Brusseau E, Schmitt C, Cloutier G, Basset O. 3D estimation of soft biological tissue deformation from radio-frequency ultrasound volume acquisitions. Med Image Anal. 2009;13(1):116-27. [PMID: 18823814]

DOI:10.1016/j.media.2008.07.003

38. Deprez JF, Cloutier G, Schmitt C, Gehin C, Dittmar A, Basset O, Brusseau E. 3D ultrasound elastography for early detection of lesions. Ev aluation on a pressure ulcer mimicking phantom. Conf Proc IEEE Eng Med Biol Soc. 2007;2007:79-82.

[PMID: 18001893]

DOI:10.1109/IEMBS.2007.4352227

39. Wang Q, Kong L, Sprigle S, Hayward V. Portable gage for pressure ulcer detection. Conf Proc IEEE Eng Med Biol Soc. 2006;1:5997-6000. [PMID: 17946732] DOI:10.1109/IEMBS.2006.260070

40. Teasell RW, Arnold JM, Krassioukov A, Delaney GA. Cardiovascular consequences of loss of supraspinal control of the sympathe tic nervous system after spinal cord injury. Arch Phys Med Rehabil. 2000; 81(4):506-16. [PMID: 10768544] DOI:10.1053/mr.2000.3848

41. Bravo-Payno P, Esclarin A, Arzoz T , Arroyo O, Labarta $C$. Incidence and risk factors in the a ppearance of heterotopic ossification in spinal cord injury. Paraplegia. 1992;30(10):740-45. [PMID: 1448303]

42. Hencey JY, Vermess M, Van Geertruyden HH, Binard JE, Manchepalli S. Magnetic resonance imaging examinations of gluteal decubitus ulcers in spinal cord injury patient s. J Spinal Cord Med. 1996;19(1):5-8. [PMID: 8673511]

43. Coelho CV, Beraldo PS. Risk factors of heterotopic ossification in traumatic spinal cord injury. Arq Neuropsiquiatr. 2009;67(2B):382-87. [PMID: 19623430] DOI:10.1590/S0004-282X2009000300002

44. Gautschi OP, Cadosch D, Frey SP , Skirving AP, Filgueira L, Zellweger R. Serum-medi ated osteogenic effect in traumatic brain-injured patients. ANZ J Surg. 2009;79(6):449-55. [PMID: 19566868] DOI:10.1111/j.1445-2197.2008.04803.x

45. Margolis DJ, Knauss J, Bilker W, Baumgarten M. Medical conditions as risk factors for pressure ulcers in an outpatient setting. Age Ageing. 2003; 32(3):259-64. [PMID: 12720610] DOI:10.1093/ageing/32.3.259

46. VA Information Resource Center (VIREC) [Internet]. Washington (DC): Department of Veterans Affairs; 
2010 (updated 2010 Dec 21; cited 2011 Jan 5). Available from: http://www.virec.research.va.gov/

47. American College of Sur geons. National surgical quality improvement program [Internet]. Washington (DC): American College of Surgeons; 2005 (cited 2011 Jan 5). Available from: http://www.acsnsqip.org/

48. Weitzenkamp DA, Jones RH, Whiteneck GG, Young DA. Ageing with spinal cord injury: Cross-sectional and longitudinal effects. Spinal Cord. 200 1;39(6): 301-9. [PMID: 11438851]

DOI:10.1038/sj.sc.3101146

49. Hitzig SL, Campbell KA, McGillivray CF, Boschen $\mathrm{KA}$, Craven BC. Understanding age effects associated with changes in secondary health conditions in a Canadian spinal cord injury cohort. Spinal Cord. 2010;48(4):330-35. [PMID: 19823193]

DOI:10.1038/sc.2009.135

50. Charlifue S, Lammertse DP, Adkins RH. Aging with spinal cord injury: Changes in selected health indices and life satisfaction. Arch Phys Med Rehabil. 2004;85(11):1848-53. [PMID: 15520980] DOI:10.1016/j.apmr.2004.03.017

51. Hitzig SL, Tonack M, Campbell KA, McGillivray CF, Boschen KA, Richards K, Craven BC. Secondary health complications in an aging $\mathrm{Ca}$ nadian spinal cord inj ury sample. Am J Phys Med Rehabil. 2008;87(7):545-55. [PMID: 18574346]

DOI:10.1097/PHM.0b013e31817c16d6

52. Edlich RF, Winters KL, Woodard CR, Buschbacher RM, Long WB, Gebhart JH, Ma EK. Pressure ulcer prevention. J Lon g Term Eff Med Implan ts. 2004; 14(4):285-304. [PMID: 15447627]

DOI:10.1615/JLongTermEffMedImplants.v14.i4.20

53. Dorner B, Posthauer ME, Thomas D. The role of nutrition in pressure ulcer prevention and treatment: National Pressure Ulcer Advisory Panel White Paper [Internet]. Washington (DC): National Pressure Ulcer Advisory Panel. 2009 (c ited 2011 Jan 5). Available from: http://www.npuap.org/Nutrition $\% 20$ White $\%$ 20Paper\%20Website\%20Version.pdf

54. Batson S, Adam S, Hall G, Quirke S. The development of a pressure area scoring system for critically ill patients: A pilot study. Intensive Crit Care Nurs. 1993;9(3):146-51. [PMID: 8400741] DOI:10.1016/0964-3397(93)90019-T

55. Salzberg CA, Byrne DW, Cayten G, Kabir R, Van Niewerburgh P, Viehbeck M, Long H, Jones EC. Predicting and preventing pressure ulcers in adults with paralysis. Adv Wound Care. 1998;11(5):237-46. [PMID: 10326341]

56. Salzberg CA, Byrne DW, Cayten CG, Van Niewerburgh P, Murphy JG, Viehbeck MA. A new pressure ulcer risk assessment scale for individuals with spinal cord injury. Am J Phys Med Rehabil. 1996; 75(2):96-104. [PMID: 8630201] DOI:10.1097/00002060-199603000-00004

57. Claudia G, Diane M, Daphney SG, Danièle D. Prevention and treatment of pressure ulcers in a university hospital centre: A correlational study examining nurses' knowledge and best practice. Int J Nu rs Pract. 2010;16(2):183-87. [PMID: 20487064] DOI:10.1111/j.1440-172X.2010.01828.X

58. Cox J, Roche S, Van Wynen E. The effects of various instructional methods on retention of kn owledge about pressure ulcers among critical care and medical-surgical nurses. J Contin Educ Nurs. 2010; 10:1-8. [PMID: 20704094]

59. Sheppard R, Kennedy P, Mackey CA. The ory of planned behaviour, skin care and pressure s ores following spinal cord in jury. J Clin Psychol Med Settings. 2006:13(4):359-67. DOI:10.1007/s10880-006-9048-1

60. Rosen J, Mittal V, Degenholtz H, Castle N, Mulsant B, Hulland S, Nace D, Rubin F . Ability, incentives, and management feedback: Organizational change to reduce pressure ulcers in a nursing home. J Am Med Dir Assoc. 2006;7(3):141-46. [PMID: 16503306] DOI:10.1016/j.jamda.2005.08.003

61. Jones ML, Mathewson CS, Adk ins VK, Ayllon T. Use of behavioral contingencies to promote prevention of recurrent pressure ulcers. Arch Phys Med Rehabil. 2003;84(6):796-802. [PMID: 12808529] DOI:10.1016/S0003-9993(02)04943-2

62. Castro MJ, Apple DF Jr, Staron RS, Campos GE, Dudley GA. Influence of complete spinal cord injury on skeletal muscle within 6 mo of injury . J Appl Physiol. 1999;86(1):350-58. [PMID: 9887150]

63. Hafer-Macko CE, Ryan AS, Ivey FM, Macko RF. Skeletal muscle changes after hemiparetic stroke and potential beneficial ef fects of ex ercise intervention strategies. J Rehabil Res Dev. 2008;45(2):261-72.

[PMID: 18566944] DOI:10.1682/JRRD.2007.02.0040

64. Urso ML. Disuse atrophy of huma n skeletal muscle: Cell signaling and potential interventions. Med Sci Sports Exerc. 2009 Sep 2. [Epub ahead of print] [PMID: 19727028] 
65. NPUAP Pre-Conference Webinar for the i nternational multidisciplinary consensus conference on the 'Issues of Avoidable and Unavoidable Pressure Ulcers in All Care Setti ngs' [Internet]. Washington (DC): National Pressure Ulcer Advisory Panel; 2009 (cited 2010 Sep 7). Available from:

http://www.npuap.org/A/

UA\%20Pre\%20Conference\%20Webinar.mov

66. Guihan M, Garber SL, Bombardier CH, Goldstein B, Holmes SA, Cao L. Predictors of pressure ulcer recurrence in veterans with spinal cord injury. J Spinal Cord Med. 2008;31(5):551-59. [PMID: 19086713]

67. Pressure ulcer prevention quick reference guide [Internet]. Washington (DC): National Pressure Ulcer Advisory Panel; 2009 (cited 2010 Nov 11). Available from: http://www.epuap.org/guidelines/ Final Quick Prevention.pdf

68. Knox DM, Anderson TM, Anderson PS. Effects of different turn intervals on skin of healthy older adults. Adv Wound Care. 1994;7(1):48-56. [PMID: 8149048]

69. Krapfl LA, Gray M. Does regular repositioning prevent pressure ulcers? J W ound Ostomy Continence Nurs. 2008;35(6):571-77. [PMID: 19018196]

70. Ballard N, McCombs A, De boor S, Strachan J, Johnson M, S mith MJ, S tephens K, Pelter MM. How our ICU dec reased the rate of hos pitalacquired pressure ulcers. J Nurs Care Qual. 2008; 23(1):92-96. [PMID: 18281882]

71. Hobbs BK. Reducing the incidence of pressure ulcers: Implementation of a turn-team nursing program. J Gerontol Nurs. 2004;30(11):46-51. [PMID: 15575191]

72. Milne CT, Trigilia D, Houle TL, Delong S, Rosenblum D. Reduc ing pressure ulcer pre valence rates in the long-term acute care setting. Ostomy W ound Manage. 2009;55(4):50-59. [PMID: 19387096]

73. McInerney JA. Reducing hospital-acquired pressure ulcer prevalence through a focused $\mathrm{p}$ revention program. Adv Skin Wound Care. 2008;21(2):75-78.

[PMID: 18349734]

DOI:10.1097/01.ASW.0000305410.58350.34

74. Bogie KM, Ho CH. Multidisciplinary approaches to the pressure ulcer problem. O stomy Wound Manage. 2007;53(10):26-32. [PMID: 17978412]

75. Anthony D, Papanikolaou P, Parboteeah S, Saleh M. Do risk assessment scales for pressure ulcers work? J Tissue Viability. 2010;19(4):132-36.

[PMID: 20036124]

DOI:10.1016/j.jtv.2009.11.006
76. Bales I, Padwojski A. Reaching for the moon: Achieving zero pressure ulcer prevalence. J Wound Care. 2009;18(4):137-44. [PMID: 19349933]

77. Saliba D, Rubenstein LV, Simon B, Hickey E, Ferrell B, Czarnowski E, Berlowitz D. Adherence to pressure ulcer prevention guidelines: Implications for nursing home quality. J Am Geri atr Soc. 2003; 51(1):56-62. [PMID: 12534846] DOI:10.1034/j.1601-5215.2002.51010.x

78. Gefen A. How much time does it take to get a pressure ulcer? Integrated e vidence from human, animal, and in vitro studie s. Ostomy Wound Manage. 2008;54(10):26-28,30-35. [PMID: 18927481]

79. Mawson AR, Biundo JJ Jr, Neville P, Linares HA, Winchester Y, Lopez A. Risk factors for early occurring pressure ulcers follo wing spinal cord injury . Am J Phys Med Rehabil. 1988;67(3):123-27. [PMID: 3377890] DOI:10.1097/00002060-198806000-00007

80. Mawson AR, Siddiqui FH, Connolly BJ, Sharp CJ, Summer WR, Biundo JJ Jr. Sacral transcutaneous oxygen tension level $\mathrm{s}$ in the spinal cord injured: Risk factors for pressure ulcers? Arch Phys Med Rehabil. 1993;74(7):745-51. [PMID: 8328898] DOI:10.1016/0003-9993(93)90037-B

81. Linder-Ganz E, Yarnitzky G, Yizhar Z, Siev-Ner I, Gefen A. Real-time finite element monitoring of sub-dermal tissue stresses in individuals with spinal cord injury: Toward prevention of press ure ulcers. Ann Biomed Eng. 2009;37(2):387-400.

[PMID: 19034666] DOI:10.1007/s10439-008-9607-8

82. Linder-Ganz E, Shabshin N, Itzchak Y, Yizhar Z, Siev-Ner I, Gefen A. Strains and stresses in subdermal tissues of the buttoc ks are gre ater in paraplegics than in healthy during sitting. J Biomech. 2008;41(3):567-80. [PMID: 18054024] DOI:10.1016/j.jbiomech.2007.10.011

83. Linder-Ganz E, Gefen A. The effects of pressure and shear on capillary closure in the microstructure of skeletal muscles. Ann Biomed Eng. 2007;35(12): 2095-2107. [PMID: 17899378] DOI:10.1007/s10439-007-9384-9

84. Mackey JR, Davis BL. Simulta neous shear and pressure sensor array for assessing pressure and shear at foot/ground interface. J Biomech. 2006; 39(15):2893-97. [PMID: 16297920] DOI:10.1016/j.jbiomech.2005.10.001

85. Stinson MD, Crawford SA, Porter -Armstrong AP. Interface pressure measurements: Visual interpretation 
of pressure maps with MS clients. Disabil Rehabil. 2008;30(8):618-24. [PMID: 17852280] DOI:10.1080/09638280701400409

86. Coggrave MJ, Rose LS. A specialist seating assessment clinic: Changing pressure relief practice. Spinal Cord. 2003;41(12):692-95. [PMID: 14639449] DOI:10.1038/sj.sc.3101527

87. Bogie K, Wang X, Fei B, Sun J. New technique for real-time interface pressure analysis: Getting more out of large image data sets. J Rehabil Res Dev. 2008;45(4):523-35. [PMID: 18712638]

DOI:10.1682/JRRD.2007.03.0046

88. Makhsous M, Lin F , Knaus E, Zeigler M, Rowl es DM, Gittler M, Bankard J, Chen D. Promote pressure ulcer healing in individuals with spinal cord injury using an individualized cyclic pressure-relief protocol. Adv Skin Wound Care. 2009;22(11):514-21. [PMID: 20026933] DOI:10.1097/01.ASW.0000305495.77649.ee

89. Alper JC, W elch EA, Ginsber g M, Bogaars H, Maguire $\mathrm{P}$. Moist wound healing under a vapor permeable membrane. J Am Acad Dermatol. 1983; 8(3):347-53. [PMID: 6833534]

DOI:10.1016/S0190-9622(83)70038-1

90. Bergstrom N, Horn SD, Smout RJ, Bender SA, Ferguson ML, Taler G, Sauer AC, Sharkey SS, Voss AC. The National Pressure Ulcer Long-Term Care Study: Outcomes of pressu re ulcer treatments in long-term care. J Am Geriatr Soc. 2005;53(10): 1721-29. [PMID: 16181171] DOI:10.1111/j.1532-5415.2005.53506.x

91. Colwell JC, Foreman MD, Trotter JP. A comparison of the efficacy and cost-ef fectiveness of two methods of ma naging pressure ulcers. Decubitus. 1993;6(4):28-36. [PMID: 8297488]

92. Barnea Y, Weiss J, Gur E. A review of the applications of the hydrofiber dressing with silver (Aquacel $\mathrm{Ag}$ ) in wound care. Ther Clin Risk Manag. 20 10;6: 21-27. [PMID: 20169033]

93. Meaume S, Vallet D, Morere MN, Téot L. Evaluation of a silver-releasing hydroalginate dressing in chronic wounds with signs of local infection. J Wound Care. 2005;14(9):411-19. [PMID: 16240620]

94. Disa JJ, Carlton JM, Goldberg NH. Efficacy of operative cure in pressure sore patients. Plast Reconstr Surg. 1992;89(2):272-78. [PMID: 1732895] DOI:10.1097/00006534-199202000-00012

95. Srivastava A, Gupta A, Taly AB, Murali T. Surgical management of pre ssure ulcers during inpatient neurologic rehabilitation: Outcomes for patients with spinal cord disease. J Spinal Cord Med. 2009; 32(2):125-31. [PMID: 19569459]

96. Relander M, Palme $r$ B. Recurrence of sur gically treated pressure sores. Scand J Plast Re constr Surg Hand Surg. 1988;22(1):89-92. [PMID: 3387926] DOI:10.3109/02844318809097940

97. Kierney PC, Engrav LH, Isik FF , Esselman PC, Cardenas DD, Rand RP. Results of 268 pressure sores in 158 patients managed jointly by plastic surgery and rehabilitation medicine. Plast Reconstr Surg. 1998;102(3):765-72. [PMID: 9727442] DOI:10.1097/00006534-199809030-00022

98. Hill ML, Cronkite RC, Ota DT, Yao EC, Kiratli BJ. Validation of home tel ehealth for pressure ulcer assessment: A study in patients with spinal c ord injury. J Telemed Telecare. 2009;15(4):196-202. [PMID: 19471032]

99. Hatzakis M Jr, Haselkorn J, Williams R, Turner A, Nichol P. Telemedicine and the delivery of health services to veterans with multiple sclerosis. J Rehabil Res Dev. 2003;40(3):265-82. [PMID: 14582530]

100. Reverse staging: The NPUAP position state ment [Internet]. Washington (DC): National Pressur e Ulcer Advisory Panel; 2010 (cited 2011 Jan 5). Available from: http://npuap.org/positn5.htm

101. Norton L, Sibbald RG. Is bed rest an effective treatment modality for pressure ulcers? Ostomy Wound Manage. 2004;50(10):40-42,44-53.

[PMID: 15509881]

102. Rish BL, Dilustro JF , Salazar AM, Schwab KA, Brown HR. Spinal cord injury: A 25-year morbidity and mortality study. Mil Med. 1997;162(2):141-48. [PMID: 9038035]

103. Patel GK, Llewe llyn M, Ha rding KG. Woundrelated osteomyelitis: A case of containment not cure. Br J Community Nurs. 2004;9(9):S6-13. [PMID: 15389154]

104. Hanson P, Delaere B, Nisolle J, Deltombe T. Pyrexia due to pyogenic sacroili itis with iliopsoas abscess after spinal cord in jury. Spinal Cord. 2004;42(11): 649-51. [PMID: 15111995]

DOI:10.1038/sj.sc.3101614

105. Citak M, Backhaus M, Meindl R, Muhr G, Fehmer T. Rare complication after V AC-therapy in the treatment of deep sore ulcers in a paraplegic patient. Arch Orth op Trauma Surg. 2010;130(12): 1511-14. [PMID: 20306199] DOI:10.1007/s00402-010-1091-6

106. Jones KR, Fennie K. Factors influencing pressure ulcer healing in ad ults over 50: An ex ploratory 
study. J Am Med Dir Assoc. 2007;8(6):378-87.

[PMID: 17619036]

DOI:10.1016/j.jamda.2007.02.011

107. Trautner BW, Darouiche RO. Prevention of urinary tract infection in patients with spinal cord injury. J Spinal Cord Med. 2002;25(4):277-83.

[PMID: 12482169]

108. Savini V, Catavitello C, Talia M, Di Berardino F, Manna A, Balbinot A, Febbo F, Carlino D, Fioritoni F, Di Bo naventura G, D'Antonio D. Ulcer infection by ESbetaL-producing Proteus mirabilis: A case report. Int J Low Extrem Wounds. 2008; 7(2):99-101. [PMID: 18483010] DOI:10.1177/1534734608316107

109. Savini V, Manna A, Di Bonaventura G, Catavitello C, Talia M, Balbinot A, Febbo F , D'Antonio D. Multidrug-resistant Enterococcus raffinosus from a decubitus ulcer: A ca se report. Int J Low Extrem Wounds. 2008;7(1):36-37. [PMID: 18372268]

110. Newman B, Lim FP. An evidence based approach to a perennial problem: Press ure ulcers. Contemp Nurse. 2001;10(1-2):102-9. [PMID: 11855012]

111. Harding K, Cutting K, Price P. The cost-effectiveness of wound management protocols of care. $\mathrm{Br} \mathrm{J}$
Nurs. 2000;9(19 Suppl):S6,S8,S10 passim. [PMID: 12271239]

112. Davies M. VHA systems redesign overview activities \& connections to research [Internet]. Washington (DC): Departmen t of Veterans Affairs; 2010. Available from: http://www.hsrd.research.va.gov/ for_researchers/cyber_seminars/archives/qip102610.pdf

This article and any supplementary material should be cited as follows:

Henzel MK, Bogie KM, Gu ihan M, Ho CH. Pressure ulcer management and research priorities for patients with spinal cord injury: Consensus opinion from SCI QUERI Expert Pa nel on Pressure Ulcer Research Implementation. J Rehabil Res Dev. 2011; 48(3):xi-xxxii.

DOI:10.1682/JRRD.2011.01.0011

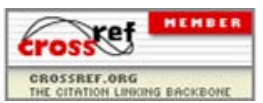


